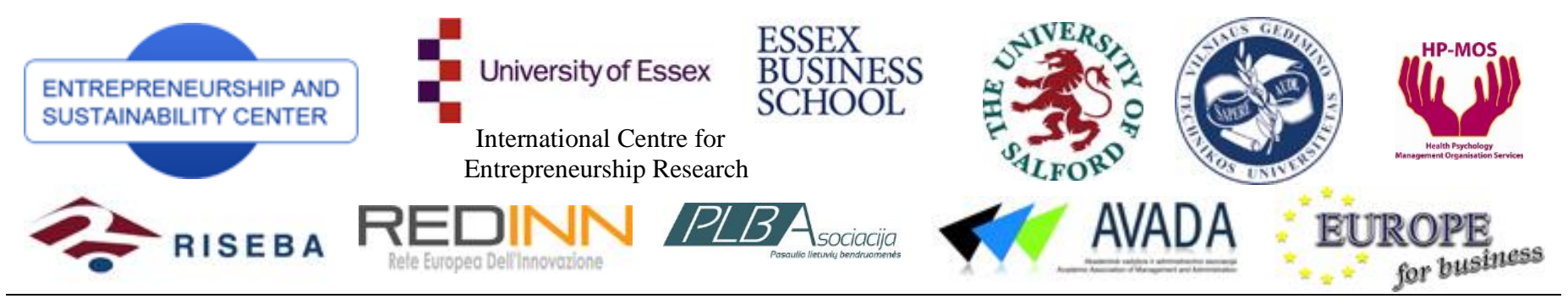

\title{
ENTREPRENEURSHIP AND SUSTAINABILITY ISSUES
}

ISSN 2345-0282 (online) http://jssidoi.org/jesi/

\section{THE INVESTIGATION OF HUMAN CAPITAL AND INVESTMENTS INTO HUMAN CAPITAL: LITHUANIA IN THE CONEXT OF THE EU}

\author{
Justina Prakapavičiūtè1, Renata Korsakienè $\dot{2}^{2,3}$ \\ 1,2 Vilnius Gediminas Techncal University, \\ Sauletekio al 11, LT-10223 Vilnius, Lithuania \\ ${ }^{3} V$ ŠL Entrepreneurship and Sustainability Center, \\ M. K. Ciurlionio str. 86A,, LT-03100 Vilnius, Lithuania \\ E-mails:. ${ }^{1}$ justina.prakapaviciute@stud.vgtu.lt, ${ }^{2}$ renata.korsakiene@vgtu.lt \\ Received 20 February 2016; accepted 16 May 2016
}

\begin{abstract}
The emergence of knowledge-based world economy has increased the demand of highly skilled labour force. On the other hand, the labour force is impacted by the level of education and the investments into education and contributes to the competitiveness of the country. The paper aims to analyse human capital and investments into human capital. Specifically we focus on high education and effectiveness of investments into high education. The investigation revealed that the focus on R\&D in Lithuania is seen as insufficient and thus, diminishes competitiveness of the country in the international context. The assessment of investments into high education let us conclude that investments are beneficial to the State in the long-term period. The insights into the development of future investigations are suggested.
\end{abstract}

Keywords: investments, human capital, return on investments, high education, R\&D.

Reference to this paper should be made as follows: Justina Prakapavičiūtė, J.; Korsakienė, R. 2016. The investigation of human capital and investments into human capital: Lithuania in the conext of the EU, Entrepreneurship and Sustainability Issues 3(4): $350-367$.

DOI: http://dx.doi.org/10.9770/jesi.2016.3.4(4)

JEL Classifications: I21, H10, H24

\section{Introduction}

The emergence of knowledge-based world economy has increased the demand of highly skilled labour force. On the other hand, the labour force is impacted by the level of education and the investments into education. Thus, a number of scientific investigations aimed to distinguish the role of education in the country's economy. Scientific researches and reports of World Bank, grounded on the international experience, in particular from Asia, revealed the relationship between education and competitiveness of developing countries (Saint 2015). Thus, competitiveness of the country is defined by the development of effective human capital. The positive effect of education at the individual level is justified by a number of various studies (Altonji 2012). The higher 


\section{The International Journal \\ ENTREPRENEURSHIP AND SUSTAINABILITY ISSUES}

ISSN 2345-0282 (online) http://jssidoi.org/jesi/

2016 Volume 3 Number 4 (June)

earnings of university graduates as well as other non-financial benefits are seen as the main outcomes of investments into high education.

The paper aims to analyse human capital and investments into human capital. Specifically we focus on high education and effectiveness of investments into high education. Thus, the paper is structured as follows. First, grounded on the prevailing scientific literature, we analyse the concepts of human capital and investments into human capital. Secondly, the factors of high education and benefits of high education are analysed. Thirdly, based on statistical data, investments into high education in Lithuania and the EU are analysed. Fourthly, the investments into education in Lithuania are assessed.

\section{The concept of human capital and investments into human capital}

In the context of the science development and the changes of surrounding environment new definitions, theories and approaches towards different issues have been suggested. The growing interest of the scientists related to the human capital and investments into human capital demonstrate the significance of the accumulation of human capital. Notably, human capital can be assessed both qualitatively and quantitatively. While qualitative approach aims to measure excellence and knowledge, contributing to the work effectiveness, quantitative approach aims to measure the number of individuals and working hours (Matiušaityte, Šarkiūnaite 2003). On the other hand, human capital is influenced by varius factors and is interrelated to the investments into human capital. The history of society's development demonstrate the close relationship between education and the level of economy development. The researchers conclude that successful development of economy depends on investments into high education (Gižienè, Markauskienė 2012, Lankauskienė 2014; Tarábková, L. 2014). Thus, the comprehensive investigation of both human capital and investments into human capital has to be analysed.

Scientific researches adopted various approaches and suggested different concepts of human capital. The scholars provided different definitions and explanations of human capital, emphasizing knowledge, skills and abilities. For instance, the notion that human capital comprises knowledge, skills, and competences and attributes, facilitating individual, social and economic well-being, appears in the scientific literature (OECD 2007). Nureyev (2010) assumes that human capital comprises innate and acquired skills, specialised and general knowledge, health, experience, motivation, contributing to the work efficiency and the higher earnings, the improved work culture and the abilities to apply acquired knowledge and skills in appropriate time and place. Human capital is supposed to be resource of knowledge, skills, experience and health, required for higher incomes in the form of the earnings (Poteliene, Tamašauskienè 2014). The scholars, investigating human capital, adopted the wide and narrow approaches. While the narrow approach to human capital emphasizes education, the wide approach to human capital emphasizes investments into education and preparation of individuals for labour market (Korsakienė et al. 2011; Korsakienė, Tunčikienė 2014; Korsakienė, Diskienė 2015). The aim to systemise definitions of human capital let us reveal that he main aspects comprise knowledge accumulated through education and work experience, leading to higher incomes and rate of return in the future. The main elements of human capital, representing skills and attributes of individuals are presented in Figure 1. 


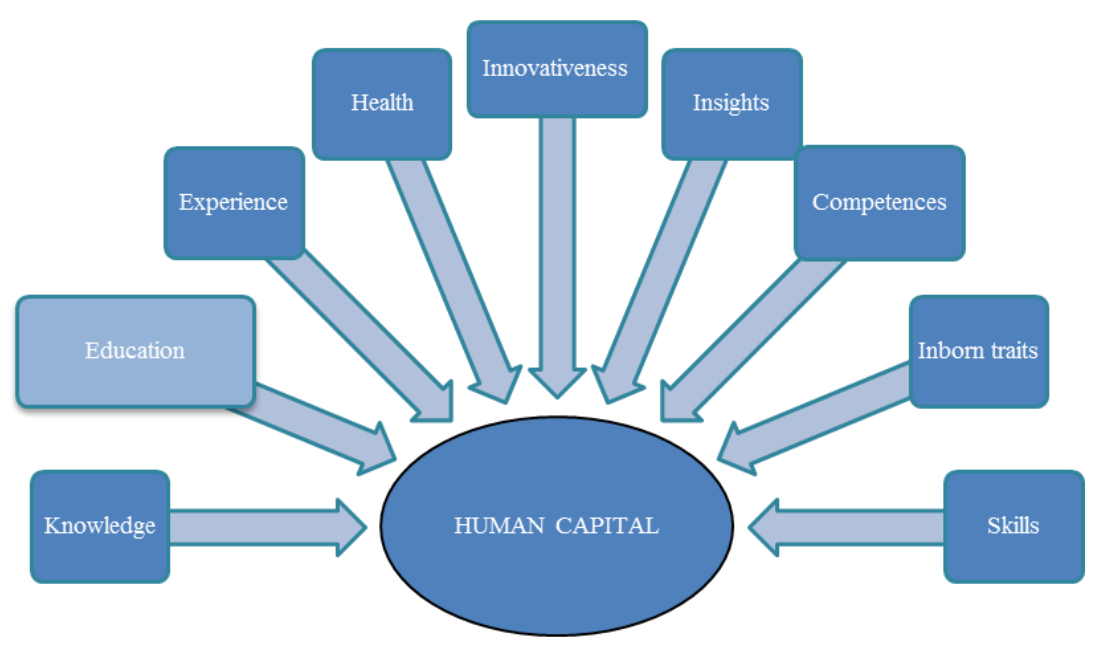

Fig. 1. The elements of human capital

Source: Developed by the authors

Investments into high education are seen as the advanced mean, leading to the improvement of life quality and providing various opportunities and capabilities for effective self-realization of individuals. Thus, the system of country's education is seen as the most significant in evaluation of the potential of country's economy development (Hazelkorn, Huisman 2008). According to Ashenfelter et al. (2003), the theory of human capital assumes education as the current investments in exchange for the better future. Hence, human capital is formed by the investments of the government, employers' and individuals (Fig. 2).

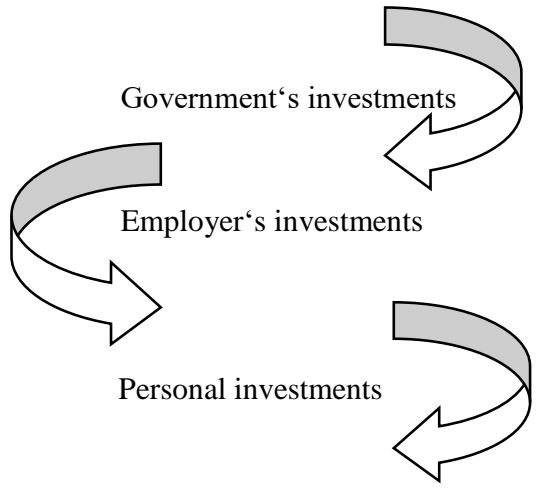

Fig. 2. The investments into human capital formation 
ENTREPRENEURSHIP AND SUSTAINABILITY ISSUES

ISSN 2345-0282 (online) http://jssidoi.org/jesi/

2016 Volume 3 Number 4 (June)

Source: Ashenfelter et al. 2003

Notably, costs incurred while investing into high education comprise a loss of personal incomes, expenditure to educational means required for the development process, expenditure to courses required for the increase of qualification. However, these costs are compensated by the increased incomes in the future. These investments improve abilities, skills and knowledge. Thus, the investments increase the effectiveness of human capital and facilitate the accumulation of human capital ( $\mathrm{Li}$ et al. 2009). To conclude, the investments despite their origin, i.e. employers', personal or government ss contribute to the return and the development of human capital (Fig. 3). While investing into human capital various costs are incurred. These costs are related to the development processes such as the courses of qualification, loss of income and the means of education. The accumulation of human capital contributes to the development of abilities, provides new knowledge, skills, develops new attributes of individuals and provides more opportunities in the labour market. These investments assure return in the future and incurred costs are compensated by the acknowledgment, self-realization and increased incomes of individuals.
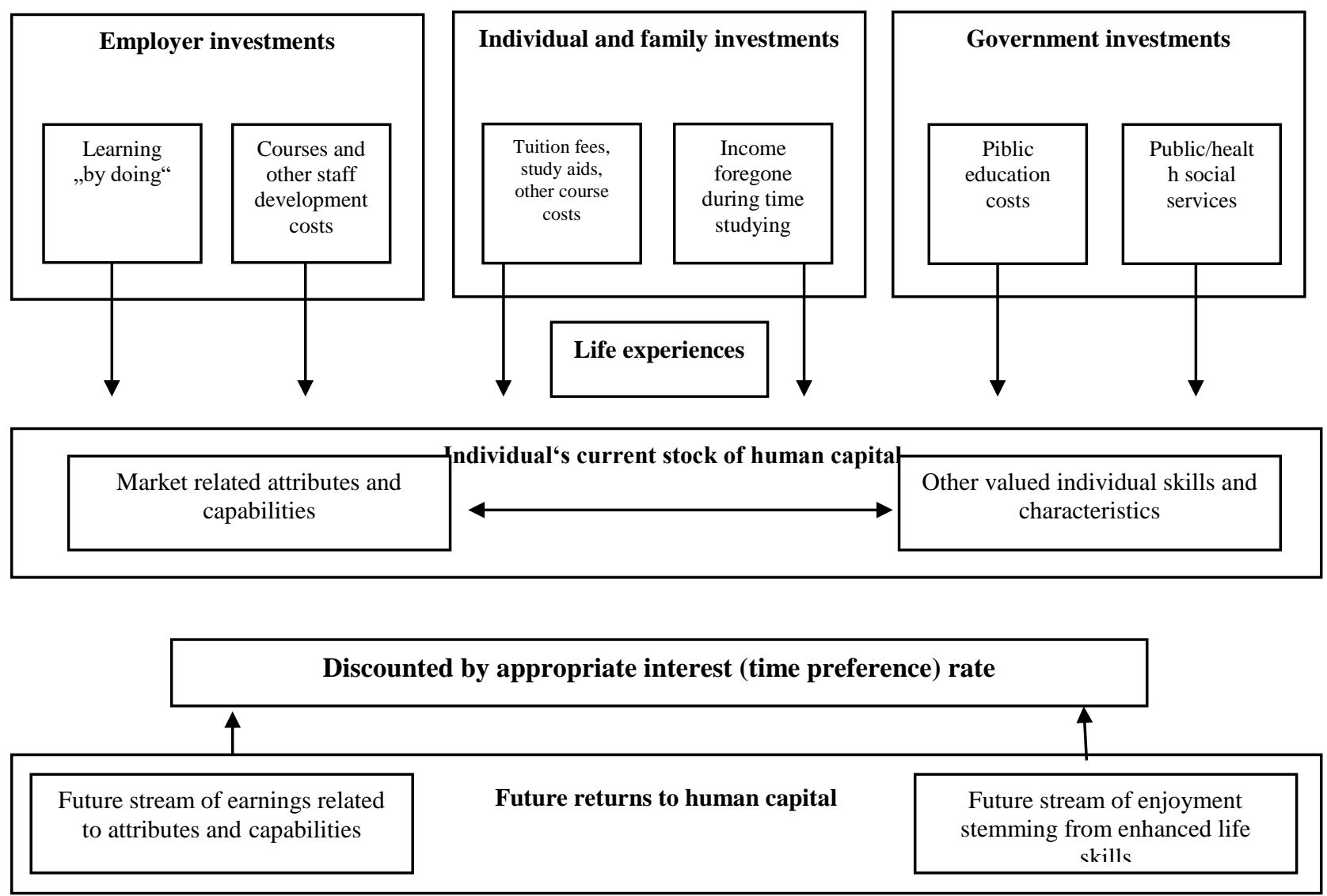

Fig. 3. The influence of investments on human capital

Source: Stroombergern et al. 2003 


\section{ENTREPRENEURSHIP AND SUSTAINABILITY ISSUES}

ISSN 2345-0282 (online) http://jssidoi.org/jesi/

2016 Volume 3 Number 4 (June)

To conclude, the investments into human capital and specifically to the high education comprise the increase of skills and abilities and the increase of the level of human capital in all society (Pargaru et al. 2009).

\section{Investments into human capital in the context of high education}

In the context of globalisation Lithuania is exposed to various challenges, changing economic, cultural and social life of the country. Notably, globalisation influenced high education and Lithuania has to actively participate in the implementation of the EU education strategy. The interaction of science and education reinforces competitiveness of country's economy and leads to the higher qualification of individuals and the lower unemployment rate (Gižienè, Barkauskas 2010).

Currently the economy is based on knowledge, innovations and improved technologies and thus, the quality of high education and the investments into human capital have become the main factors of economy progress. Scientific literature distinguishes six main factors, impacting education of qualified individuals (Fig. 4). 


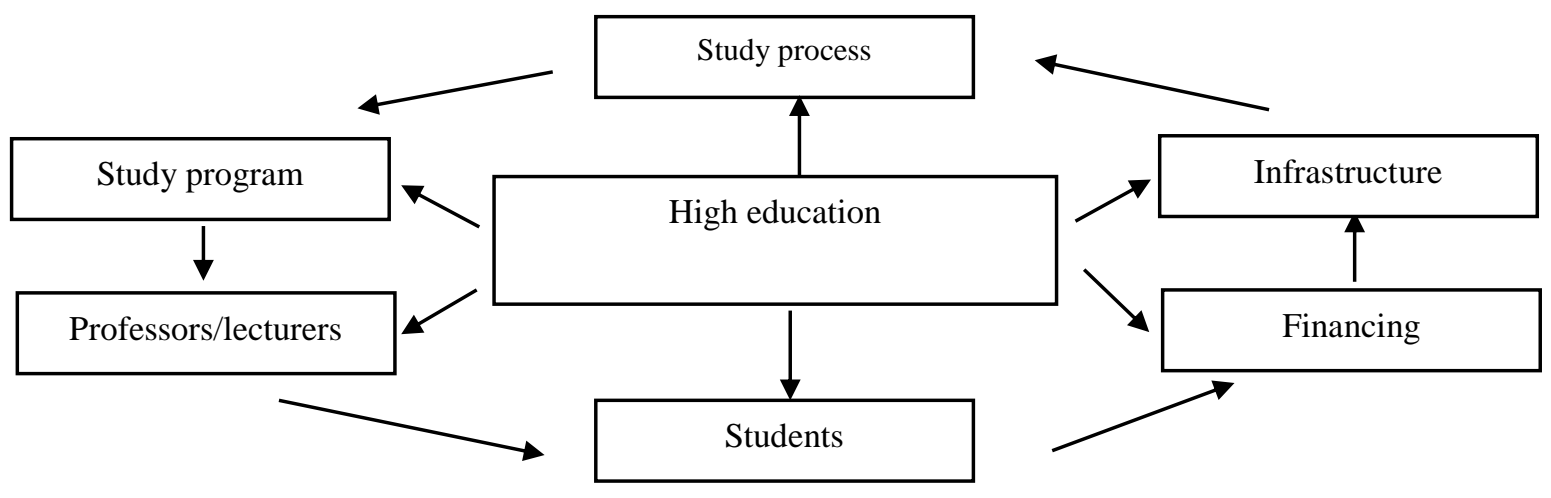

Fig. 4. The factors of high education Source: Gižiene, Barkauskas 2010

The significance of investments into human capital has been investigated by the scientists since mid-XX century. The scholars assume that investments are the main factor of economy growth, impacting the development of new technologies. Thus, the relationship between economy growth and investments into human capital has been observed. The development of technologies encourages the demand of human capital and higher investments into high education assure higher future earnings, training and development (Narayan, Smyth 2007). The growth of economy and development of country depends on the investments into high education and improves life quality of inhabitants and competitiveness of country (Mansur et al. 2010). Scientific investigations confirm that high education leads to increased incomes of individuals. On the other hand, acknowledgment, life quality, selfrealisation, moral motivation and self-esteem of individuals are seen as the most important factors despite the financial benefits (Gižienè, Vasiliauskaite 2007). Considering the fact that the individual adapts better to various changes in the market and the probability that individual may become unemployed decreases, high education is beneficial for the learner, his/her family and other people. The scholars comment that in various foreign countries 66-80 percent of all personal incomes are influenced by education and the growth of qualified individuals influences the economy growth (Seniūnaite 2002). To conclude, the benefits of investments to high education are received by both the individual and society (Table 1).

Table 1. The benefits of high education from the perspective of the individual and society

\begin{tabular}{|c|c|c|c|}
\hline \multicolumn{2}{|c|}{ The benefits of individual } & \multicolumn{2}{|c|}{ The benefits of society } \\
\hline Economic & Social & Economic & Social \\
\hline $\begin{array}{l}\text { The growth of incomes due to the } \\
\text { growth of work compensation }\end{array}$ & $\begin{array}{l}\text { The higher possibilities to be } \\
\text { employed and advanced work } \\
\text { places }\end{array}$ & $\begin{array}{l}\text { The growth of incomes before } \\
\text { taxes }\end{array}$ & $\begin{array}{c}\text { The improvement of } \\
\text { international relationships }\end{array}$ \\
\hline $\begin{array}{l}\text { The growth of retirement pension } \\
\text { due to higher work compensation }\end{array}$ & $\begin{array}{l}\text { The satisfaction due to } \\
\text { development processes }\end{array}$ & The growth of economy & $\begin{array}{l}\text { The growth of knowledge- } \\
\text { based economy and } \\
\text { implementation of } \\
\text { innovations }\end{array}$ \\
\hline The decrease of unemployment risk & $\begin{array}{l}\text { Better adaptation in the labour } \\
\text { market in the time of changes }\end{array}$ & Additional incomes & $\begin{array}{c}\text { The development of } \\
\text { democratic relationships }\end{array}$ \\
\hline
\end{tabular}

Source: developed by the authors

The educated individual is able to apply knowledge in real life, to implement different processes and faster adapts to the fast changing market, innovations and new requirements. The resources devoted to human capital, to the development and the creativity of the potential of human capital influence benefits and incomes, assuring life quality. Scientific investigations confirm the long term effect of the investments into high education. For instance, McMahon (2007) distinguishes several objectives leading to the positive impact of high education to GDP per capita and the rate of earnings: the influence to health, impacting lower mortality rate, longer work life 
expectancy rate of individuals and general rate of health in the society. The effectiveness of the investments to high education is defined by the lower crime rate, the diminishment of poverty and social exclusion and the number of new technologies and research and development (R\&D). From the perspective of fiscal policy the investments into education influence incomes before taxes (Gupta et al. 2002; Gižienè, Markauskienė 2012). Woessmann and Schuetz (2006) confirmed that the level of education increases earnings and leads to the higher taxes and incomes of the State. Considering the fact that incomes before taxes comprise considerable part of the State budget, the positive impact to the society has been observed.

\section{Investments into high education in the context of the EU}

The development of high education, performance of scientific researches, and development of lifelong learning depend on the country's economy and financing policy. Notably, countries have to focus on the development of innovations. Thus, public expenditure comprises a substantial part and contributes to the sustainability of high education. On the other hand, aiming to assure quality of high education, private financing has to be combined together with the financing of government (European Commission 2011). The investments into education, learning and lifelong learning are the main priorities defined in the strategy "Europe 2020". The development of human capital influence innovations, scientific researches and contributes to the diminishment of youth unemployment and the growth of employment rate. Thus, the qualified people assure prosperity of the society and contribute to the development of knowledge based economy (European Commission 2011). Notably, R\&D is necessary to the development and growth of knowledge based economy. Thus, R\&D is one of the main targets defined in the EU strategy. The capacity of R\&D leads to the higher competitiveness of country in the international context, contributes to the development of new products and services and increases opportunities of the companies to earn higher profits. Aiming to encourage R\&D in Lithuania, the investments provided by the government has to be increased. The government's share of total spending on R\&D and education let us compare Lithuania in the context of the EU (Fig. 7).

8

6

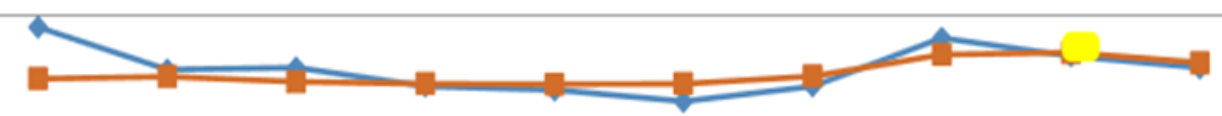

4

2

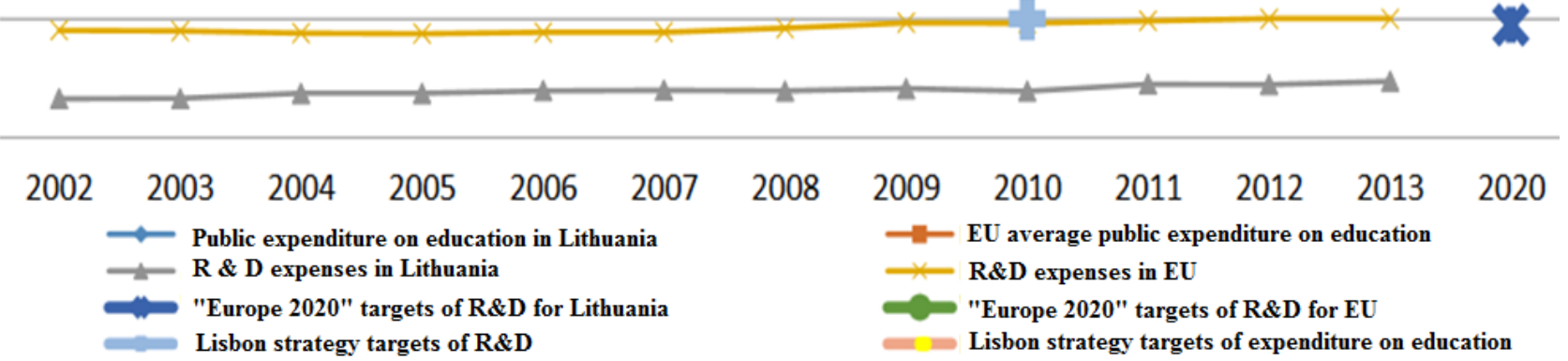

Fig. 7. Average expenditure on R\&D and education (\% GDP) Source: Statistics Lithuania 
Considering the fact that the focus of the EU is put on education, the targets of R\&D and innovations were defined in both Lisbon strategy and the strategy „Europe 2020“. Lisbon strategy defined that the average expenditure on R\&D in the EU had to comprise 2\% of GDP in 2010. However, Lithuania lagged behind the EU and the achieved indicator was about $0.78 \%$ in 2010 . Meanwhile, the EU average was about $1.93 \%$. The strategy "Europe 2020" defined the target to be reached for Lithuania by the year $2020-1.9 \%$. The target to be reached for the EU should be 3\% of GDP. Notably, the indicator of Lithuania was about $0.95 \%$ of GDP in 2014 and was below the EU average, which made about $2.01 \%$ (the investments of the EU structural funds for the development of human capital in 2013). These observations let us conclude that the EU reached the targets defined in the Lisbon strategy. Meanwhile, the indicator of Lithuania is considerably lower and the amount of expenditure in comparison to GDP has been growing slower. Lithuania significantly lags behind the EU average and the targets of the strategy are not achieved. Thus, the inappropriate focus on R\&D and the development of technologies in the country negatively influence country's competitive advantage in comparison to other countries. These trends diminish the potential and the pace of integration of economy. Notably, Lithuania's public expenditure on education is seen as favourable in comparison to expenditure on R\&D (European Commission 2013). Figure 7 let us observe that in the investigated period Lithuania's public expenditure on education fluctuated and comprised about 5\% of country's GDP. The indicator of the EU was very similar in the observed period. Meanwhile, the indicator of Lithuania was higher than the EU average in 2004 and in 2009.

Lisbon strategy defined the targets of education, i.e. 5.5\% of GDP to be reached in 2010. While the EU average was $5.41 \%$, the indicator of Lithuania was 5.36 in 2010. Thus, we can conclude that both the indicators of Lithuania and the EU were closer to the targets of the strategy and the amount of expenditure in comparison to GDP was stable. The financing of Lithuanian education system is seen as sufficient and the integration processes are at the appropriate level (Ministry of Education and Science 2013).

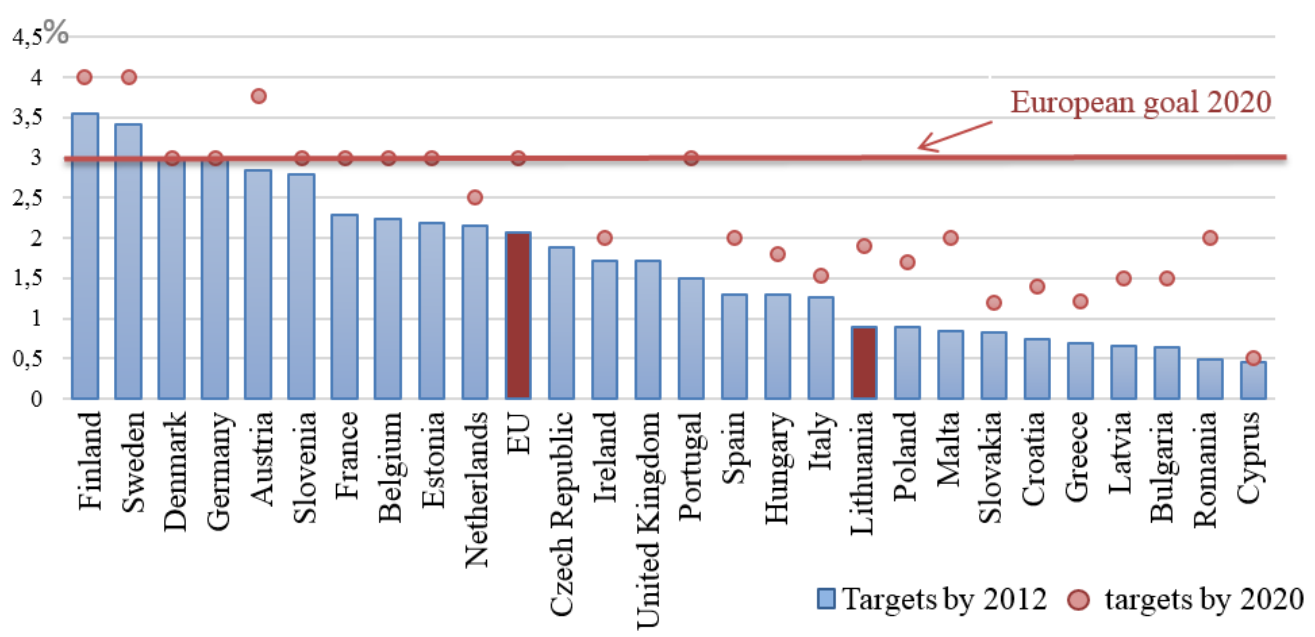

Fig. 8. Targets of R\&D to be reached by 2020 (\% of GDP)

Source: European Commission 2012

Figure 8 represents the targets of the EU countries defined in 2012. Some countries such as Finland and Sweden have adopted the highest targets $-4 \%$ of GDP and are seen as successful. Meanwhile, Cyprus defined the lowest target $-0.67 \%$ of GDP. Some countries such as Germany and Denmark are very close to the defined targets. For instance, Italy defined less ambitious targets - 1.53 of GDP. Meanwhile, Romania, Portugal, Malta and Lithuania lag behind defined targets. These observations let us conclude, that larger economies are tended to 
invest more into R\&D. On the other hand, weaker economies, aiming to achieve the EU average, are seen as the disadvantageous and require more investments. Statistical data let us define the groups of countries:

- The member States, which achieved defined targets or are very close to the defined targets such as Slovenia, Cyprus, Denmark and Germany. This group comprise countries with very high R\&D intensity (Denmark and Germany) and very low R\&D intensity (Cyprus). These countries defined lower targets in comparison to the national context and are defined as less ambitious.

- The member States, which are tended towards the achievement of targets. Considering the progress in 2007-2012, this group comprise such countries as Estonia, Hungary, Ireland, Poland, Slovakia and Belgium.

- The member States which require the increase of the R\&D intensity, aiming to achieve defined targets: Austria, Finland, France, Italy, the Netherlands and Spain.

- The member States which require significant increase of the R\&D intensity, aiming to achieve defined targets: Bulgaria, Greece, Latvia, Lithuania, Malta and Romania.

- The member States which has to change decreasing trends of the R\&D intensity: Sweden, Portugal and Croatia.

- The member States which has not defined the targets of the R\&D intensity: UK and Czech Republic.

Insufficient level of high education restricts the opportunities of countries to become competitive and productive. The performance of R\&D influence the qualification of personnel, the number of investments, the opportunities to integrate knowledge into study processes, the opportunities to achieve both financial and non-financial objectives. Thus, the strong base of $R \& D$ helps to develop young researchers, to increase human capital, to update related activities and expand the performance of science (European Commission 2012).

The strategy "Europe 2020" defined the targets for a number of high education graduates (Strategy "Europe 2020" targets 2015). The plan comprises shorter period of studies at high education institutions and to increase the share of people aged 30-34 year with high education by $40 \%$. Table 2 provides comparison of Lithuania and the EU considering different age groups.

Table 2. The shares of people with secondary education, high education and school dropout rates in Lithuania and the EU

\begin{tabular}{|c|c|c|c|c|c|c|c|c|c|c|}
\hline & $\mathbf{2 0 0 6}$ & $\mathbf{2 0 0 7}$ & $\mathbf{2 0 0 8}$ & $\mathbf{2 0 0 9}$ & $\mathbf{2 0 1 0}$ & $\mathbf{2 0 1 1}$ & $\mathbf{2 0 1 2}$ & $\mathbf{2 0 1 3}$ & $\mathbf{2 0 1 4}$ \\
\hline $\begin{array}{c}\text { Lithuania } \\
\begin{array}{c}\text { The share of people aged 20-24 with } \\
\text { secondary education (\%) }\end{array}\end{array}$ & 72,4 & 72,7 & 72,3 & 73,4 & 73,4 & 74,6 & 74,9 & 74,9 & 73,2 \\
\hline $\begin{array}{c}\text { The share of people aged 30-34 year with } \\
\text { high education (\%) }\end{array}$ & 39,4 & 36,4 & 39,9 & 40,4 & 43,8 & 45,7 & 48,6 & 51,3 & 53,3 \\
\hline $\begin{array}{c}\text { School dropout rate of people aged 18-24 } \\
\text { year (\%) }\end{array}$ & 8,8 & 7,8 & 7,5 & 8,7 & 7,9 & 7,4 & 6,5 & 6,3 & 5,9 \\
\hline $\begin{array}{c}\text { The EU } \\
\begin{array}{c}\text { The share of people aged 20-24 with } \\
\text { secondary education (\%) }\end{array}\end{array} \quad 65,2$ & 65,3 & 65,3 & 65,2 & 64,9 & 64,9 & 64,8 & 64,8 & 65,2 \\
\hline
\end{tabular}


ENTREPRENEURSHIP AND SUSTAINABILITY ISSUES

ISSN 2345-0282 (online) http://jssidoi.org/jesi/

2016 Volume 3 Number 4 (June)

\begin{tabular}{|c|c|c|c|c|c|c|c|c|c|}
\hline $\begin{array}{c}\text { The share of people aged 30-34 year with } \\
\text { high education (\%) }\end{array}$ & 29 & 30,1 & 31,2 & 32,3 & 33,8 & 34,8 & 36 & 37,1 & 37,9 \\
\hline $\begin{array}{c}\text { School dropout rate of people aged 18-24 } \\
\text { year (\%) }\end{array}$ & 15,3 & 14,9 & 14,6 & 14,2 & 13,9 & 13,4 & 12,7 & 11,9 & 11,2 \\
\hline
\end{tabular}

Source: Statistics Lithuania

Considering the share of people aged 20-24 year with secondary education, Lithuania is ahead of a number of the EU countries. For instance, Lithuania was $10^{\text {th }}$ out of 28 the EU countries considering the share of people aged 20-24 year with secondary education in 2014. Figure 9 provides the shares of people with high education and the targets of countries by the year 2020 .

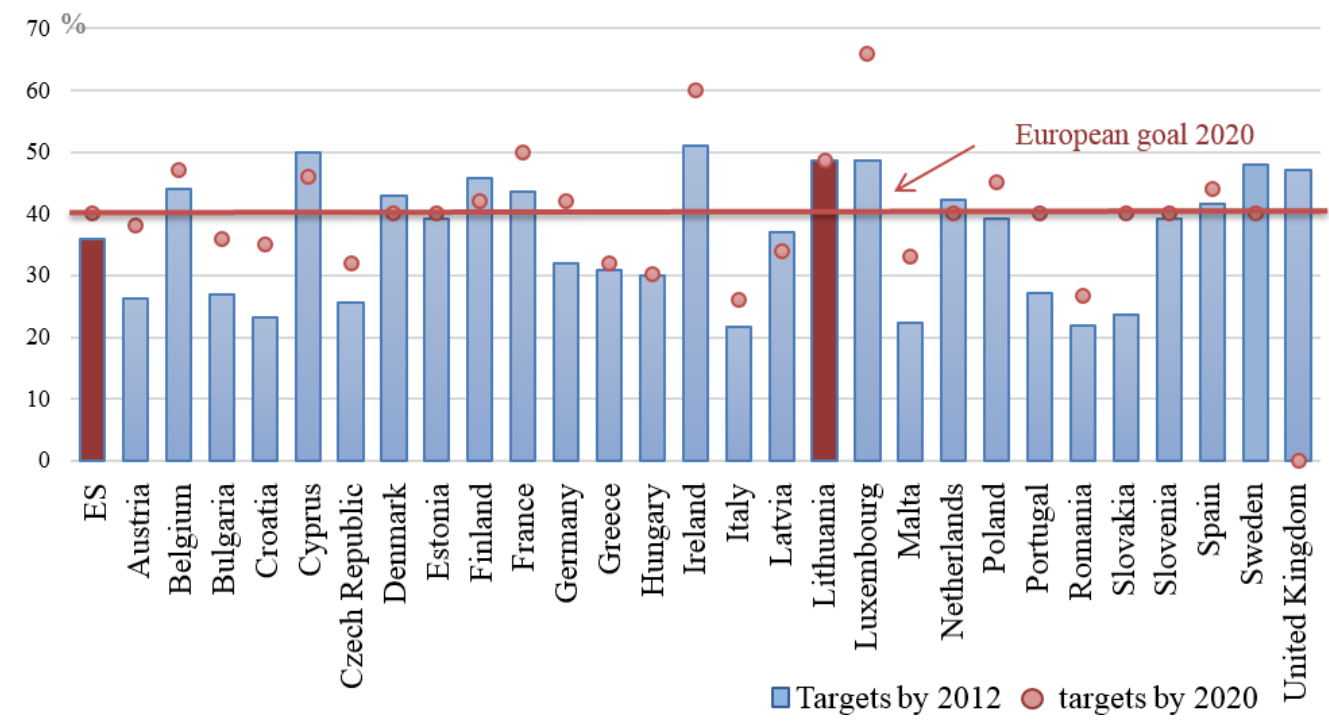

Fig. 9. The shares of people with high education and the targets of the EU countries by the year 2020

Source: European Commission 2012

Considering the level of education, the groups of the countries can be defined:

- The member States which are below the $40 \%$ target. These countries are seen as less progressive or haven't demonstrated the appropriate progress in recent years. For instance, in Bulgaria the share of people with high education comprise $26.9 \%$ and the change rate in the period of 2009-2012 was negative $-1.21 \%$. Thus, the possibilities to achieve national target (36\%) are low.

- The member States which are below the $40 \%$ target. These countries are seen as very progressive in recent years. The following changes can be traced: in Malta (2.1\%), in Czech Republic (13.5\%), in Italy $(21.7 \%)$ and in Poland (39.1\%). Notably, Estonia defined the similar target to the EU; however the target lagged behind by $40 \%$ in 2012.

- The member States which are above the $40 \%$ target. These countries lost the pace in the last few years. The group comprises such countries as Ireland and France which defined very ambitious national targets. However, the targets went' achieved. 
- The member State countries which are above the $40 \%$ target and progress in the last few years (Luxemburg, Sweden, UK and Lithuania). These countries achieved the national targets (UK hasn't defined national target).

Notably, the skills of lifelong learning are another target of the strategy "Europe 2020". The long-life studies are interrelated with the development of abilities, the development and the adaptation to new technologies and the changes of the market. Aiming to involve more people into life-long process, especially low qualified people, the target was defined to involve at least $15 \%$ of adults into life-long activities by the year 2020 .

The data provided in Figure 10 let us conclude that the indicator of life-long learning in Lithuania comprise 5$6 \%$ and the EU average - more than 10\%. Considering current context of Lithuania and the opportunities, the targets of adults education in strategic documents are lower that the EU average. The targets are to achieve 8\%

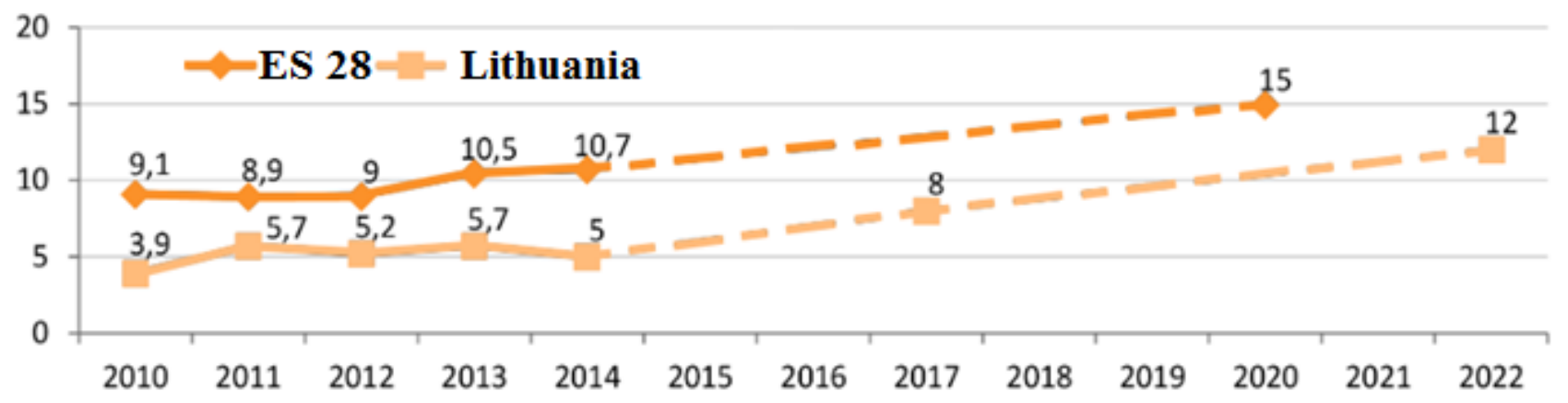

by 2017 and $12 \%$ by the year 2020 of all people aged $25-64$.

Fig. 10. Life-long learning

Source: The strategy „Europe 2020“

Considering the level of adults' education and its significance in the participation of long-life learning activities, Lithuania maintains the opportunities to develop adults' education. On the other hand, this indicator doesn't reach the EU average, what let us conclude that Lithuania is not able to catch these opportunities. The share of people with the lowest education is the smallest among the EU countries and comprises 6.6\%. In Czech Republic, Slovakia, Estonia and Poland the share is below 10\%. Meanwhile, in some South European countries the share of people without secondary education comprises more than $40 \%$ (Spain, Italy) or is close to $60 \%$ (Malta, Portugal) (Fig. 11). 
ENTREPRENEURSHIP AND SUSTAINABILITY ISSUES

ISSN 2345-0282 (online) http://jssidoi.org/jesi/

2016 Volume 3 Number 4 (June)

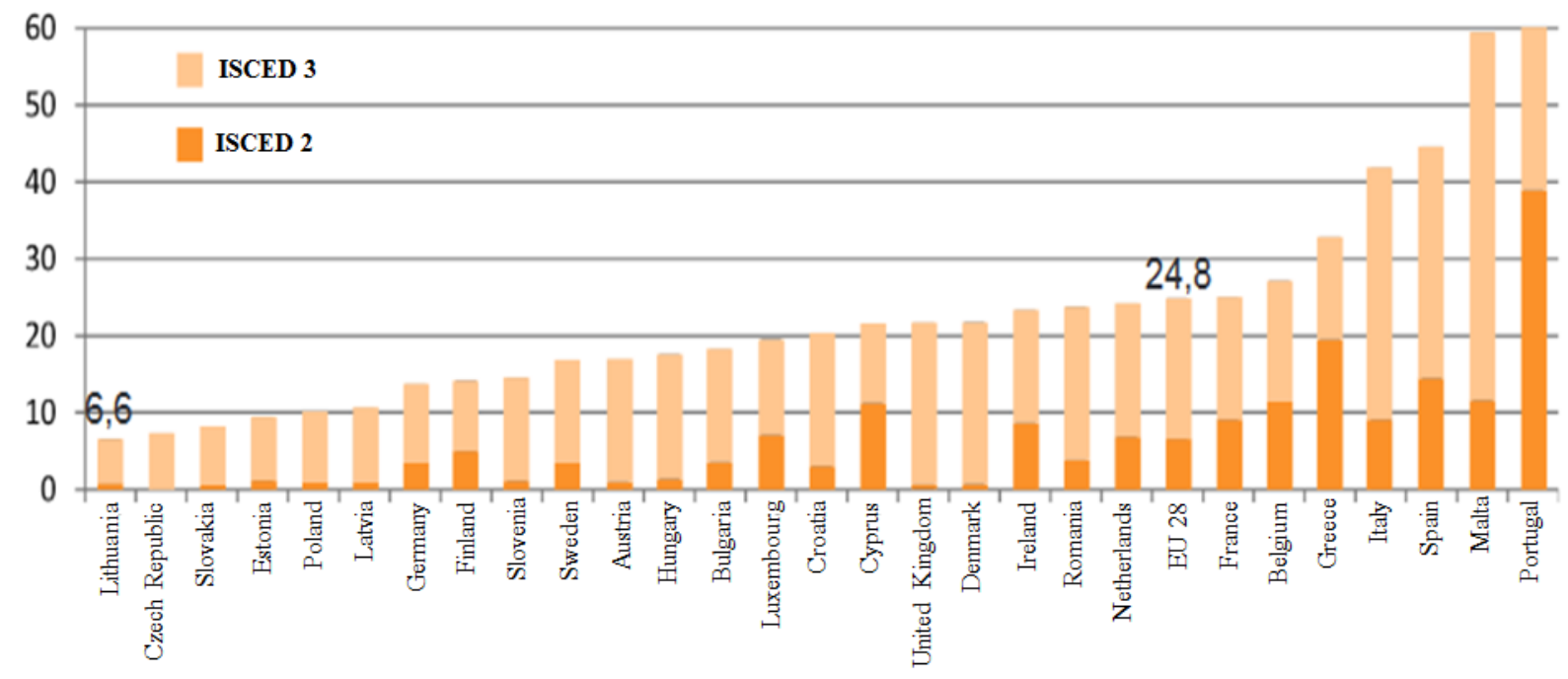

Fig. 11. The level of adults'education in the EU countries

Source: Eurostat

Statistical data provided in the Eurostat let us conclude that the participation in the programs of life-long learning is impacted by the obtained formal education, status of employment, professional category and age. The individuals with the lowest qualification or without qualification and unemployed people are tended to be passive in the education processes.

\section{The assessment of investments into high education: a case of Lithuania}

The studies confirm that public spending in education is justified by the social rate of return (Gupta et al. 2002). Meanwhile, economic return can be measured by the assessment of the relationship between compensation level and education. Hence the effectiveness of investments into human capital remains the issue requiring further investigation. The investments into human capital are beneficial to the individual and the society. Thus, the benefit is distinguished to the private and public (BIS research 2013). For instance, Glaeser et al. (2004) stated that the investments into human capital led to the democracy in South Korea and Taiwan.

Notably, various methods assessing the effectiveness of private and public investments into education are applied by foreign and Lithuanian scientist. The most popular methods applied in the scientific works are provided in Table 3. 
ENTREPRENEURSHIP AND SUSTAINABILITY ISSUES

ISSN 2345-0282 (online) http://jssidoi.org/jesi/

2016 Volume 3 Number 4 (June)

Table 3. The assessment methods of investments

\begin{tabular}{|c|c|c|}
\hline $\begin{array}{r}\text { The model } \\
\end{array}$ & Calculation & Description \\
\hline The model of Luca & $y=A k^{\alpha}(u h) 1-\alpha(h a)^{\gamma}$ & $\begin{array}{l}\mathrm{y} \text { - productivity, } \\
\mathrm{A} \text { - exogenous constant } \\
\mathrm{k} \text { - physical capital, } \\
\mathrm{u} \text { - the share of time for production/product, } \\
\mathrm{h} \text { - the representative of human capital, } \\
\text { ha - the average of human capital in economy }\end{array}$ \\
\hline The model of Romer & $Y=H_{Y}^{\alpha_{L} \beta} \int_{0}^{A} X(i)^{1-\alpha-\beta} d i_{x}$ & $\begin{array}{l}\text { Hy - human capital employed excluding R\&D; } \\
\mathrm{L}-\text { labor force. }\end{array}$ \\
\hline The model of W. McMahon & $y_{t}=\alpha_{1} s_{t-20}+\alpha_{i 2} D_{i, t-10}+\varepsilon_{1}$ & $\begin{array}{l}y \text { - the growth of GDP per capita; } \\
S \text {-the ratio of investments into human capital and the } \\
\text { earnings of individual; } \\
\text { D - the investments into physical capital, } \\
\text { e1,e2, e3 - interference. }\end{array}$ \\
\hline The model of G. Psacharopoulos & $\begin{array}{l}\text { Inner Return Rate for } \\
\left.\text { individual }=\bar{W}_{\bar{W}_{w}-\bar{W}_{Q}} \bar{W}_{2}+C_{w}\right)\end{array}$ & $\begin{array}{l}\mathrm{Wu} \text { - the earnings of a university graduate; } \\
\mathrm{Ws} \text { - the earnings of secondary school graduates, } \\
\mathrm{Cu} \text { - direct costs of university education }\end{array}$ \\
\hline
\end{tabular}

Source: Gižienè, Vasiliauskaitè 2007; Gižienè, Markauskiene 2012

The method developed by Psacharopoulos (1995) assessing the investments into high education, is seen as the most common method applied in scientific literature. The method aims to assess inner return rate for individual. The method belongs to the group of methods defined as costs-benefit analysis. Aiming to estimate inner return rate (IRR), the "pessimistic" scenario has been selected. Thus, the assumptions have been made:

- The earnings of university graduates increases $10 \%$ per year in five years period. The assumption was justified considering the growth of minimal earnings in last four years.

- Discount rate is 3.5\%. The assumption was justified considering the data of 2014 when the interest rate was $2.5-3.5 \%$.

- Despite the fact that work age of men and women is different, we assume that work age is equal to 43 years. Thus, people aged 19-62 are active in labour market.

Tables 4 and 5 provide the data related to the public spending and earnings of the individual in 2014 .

Table 4. The public spending per one student in 2014

\begin{tabular}{|l|r|}
\hline \multicolumn{2}{|c|}{ Public spending } \\
\hline The direct costs per one student & 3300 \\
\hline Minimal earnings per one year & $300 \times 12=3600$ \\
\hline Unpaid income taxes $(15 \%)$ per one year & $(300-166) \times 0,15 \times 12=241,20$ \\
\hline $\begin{array}{l}\text { Unpaid social security insurance tax and } \\
\text { compulsary health insurance tax, } 9 \%\end{array}$ & $((300 \times 0,06)+(300 \times 0,03)) \times 12=324$ \\
\hline \multicolumn{1}{|c|}{ Total: } & $\mathbf{7 4 6 5 , 2}$ \\
\hline
\end{tabular}

Source: Statistics Lithuania 
Considering the data of Statistics Lithuania in 2014, direct costs per one student was 330 EUR, minimal annual earnings - 3600 EUR and unpaid taxes comprised 565.20 EUR.

Table 5. The increase of earnings of university graduates

\begin{tabular}{|c|c|c|c|c|c|c|c|c|}
\hline \multicolumn{2}{|c|}{ The earnings in 2014} & $\begin{array}{l}10 \% \text { per } 5 \\
\text { years }\end{array}$ & $\begin{array}{l}10 \% \text { per } \\
5 \text { years }\end{array}$ & $\begin{array}{l}10 \% \text { per } 5 \\
\text { years }\end{array}$ & $\begin{array}{l}10 \% \text { per } 5 \\
\text { years }\end{array}$ & $\begin{array}{l}10 \% \text { per } \\
5 \text { years }\end{array}$ & $\begin{array}{l}10 \% \text { per } \\
5 \text { years }\end{array}$ & $\begin{array}{l}10 \% \text { per } \\
5 \text { years }\end{array}$ \\
\hline Average earnings & 580 & 638 & 701,8 & 771,98 & 849,18 & 934,10 & 1027,51 & 1130,26 \\
\hline Incomes before taxes & 491 & 562,48 & 642,87 & 731,29 & 828,57 & 934,1 & 1027,51 & 1130,26 \\
\hline Tax exempt incomes & 89 & 75,52 & 58,93 & 40,69 & 20,61 & - & - & - \\
\hline Income taxes, $15 \%$ & $\begin{array}{c}(491 \times 0,15) \times \\
12=883,80\end{array}$ & 1012,464 & 1157,166 & 1316,322 & 1491,426 & 1681,38 & 1849,518 & 2034,468 \\
\hline $\begin{array}{l}\text { Social security insurance } \\
\text { tax and compulsary health } \\
\text { insurance tax, } 9 \%\end{array}$ & $\begin{array}{c}((580 \times 0,06) \\
+(580 \times 0,03) \\
\times 12=626,40\end{array}$ & 689,04 & 757,944 & 833,74 & 917,11 & 1008,83 & 1109,71 & 1220,68 \\
\hline Total: & 1510,2 & 1701,504 & 1915,11 & 2150,062 & 2408,536 & 2690,21 & 2959,228 & 3255,148 \\
\hline
\end{tabular}

Source: Statistics Lithuania

The average earnings were equal to 580EUR in the analysed period. Considering tax exempt incomes and taxes, the pessimistic scenario let us conclude that benefits of the government from the university graduate are 1510.20 EUR. Table 6 provides information related to the cash flows, generated every five years due to the growth of the individual earnings.

Table 6. The cash flow of individual in the period of working age

\begin{tabular}{|c|c|c|c|c|c|c|c|}
\hline Years & Cash flow & Years & Cash flow & Years & Cash flow & Years & Cash flow \\
\hline 19 & $-7465,2$ & 31 & 1701,504 & 43 & 2408,536 & 55 & 2959,23 \\
\hline 20 & $-7465,2$ & 32 & 1701,504 & 44 & 2408,536 & 56 & 2959,23 \\
\hline 21 & $-7465,2$ & 33 & 1915,11 & 45 & 2408,536 & 57 & 2959,23 \\
\hline 22 & $-7465,2$ & 34 & 1915,11 & 46 & 2408,536 & 58 & 3255,15 \\
\hline 23 & 1510,2 & 35 & 1915,11 & 47 & 2408,536 & 59 & 3255,15 \\
\hline 24 & 1510,2 & 36 & 1915,11 & 48 & 2690,21 & 60 & 3255,15 \\
\hline 25 & 1510,2 & 37 & 1915,11 & 49 & 2690,21 & 61 & 3255,15 \\
\hline 26 & 1510,2 & 38 & 2150,062 & 50 & 2690,21 & 62 & 3255,15 \\
\hline 27 & 1510,2 & 39 & 2150,062 & 51 & 2690,21 & \multirow{4}{*}{\multicolumn{2}{|c|}{ IRR 4\% }} \\
\hline 28 & 1701,504 & 40 & 2150,062 & 52 & 2690,21 & & \\
\hline 29 & 1701,504 & 41 & 2150,062 & 53 & 2959,23 & & \\
\hline 30 & 1701,504 & 42 & 2150,062 & 54 & 2959,23 & & \\
\hline
\end{tabular}


Calculated IRR let us conclude, that the value of IRR is higher than discount rate $(4 \%>3.5 \%)$. Thus, the investments into high education are beneficial to the State. The obtained data, related to the other the EU States are provided in Figure 6.

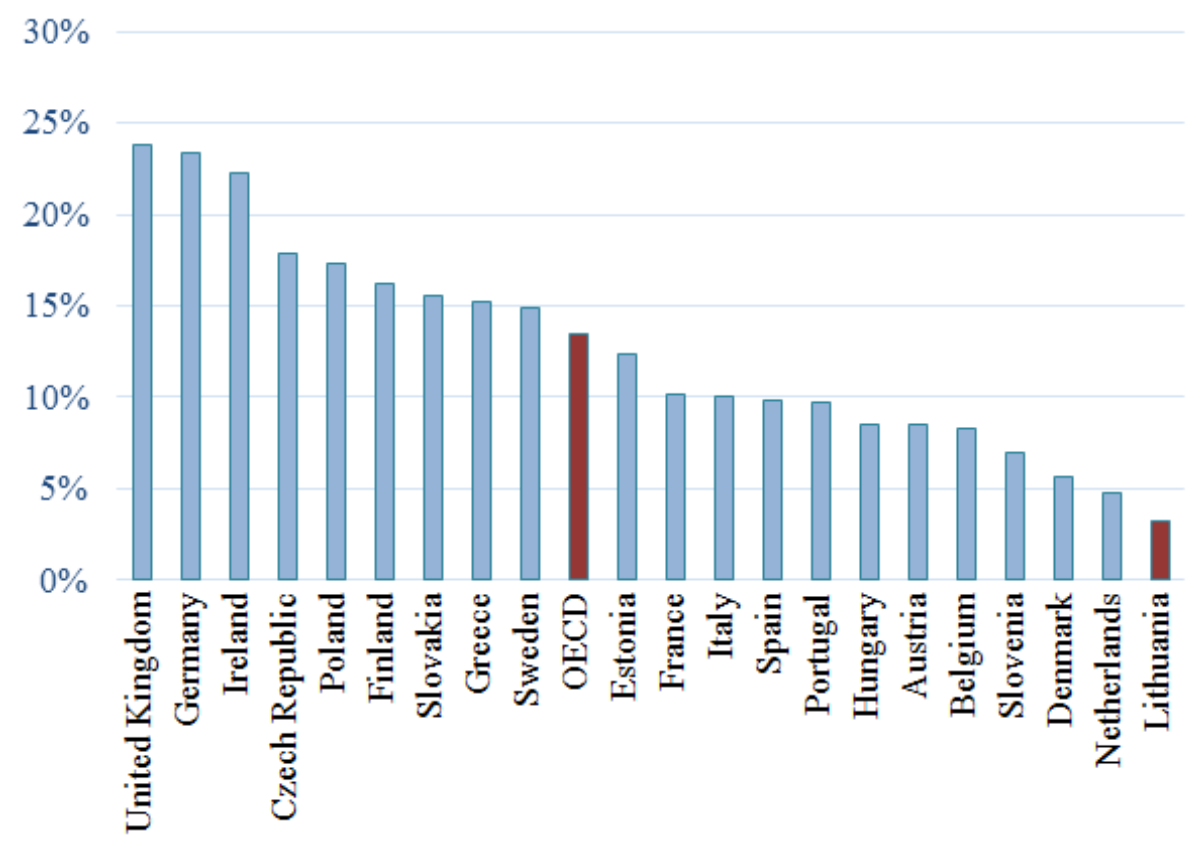

Fig. 6. The return rate of investments into high education in the EU

Source: OECD 2014

Notably, the return rate of Lithuania is lower than the OECD average (13\%). Therefore, the considerable efforts of the government have to be increased.

\section{Conclusions}

1. The comparative analysis of the scientific literature let us observe, that human capital comprises knowledge, abilities and competencies, leading to the personal, social and economic well-being. Human capital depends on the factors such as the level of education at the both individual's and the country's level. Education depends on the investments into high education of both the government and the individual. The higher the share of the investments assigned to the education, the higher the value of human capital. Therefore, the competitiveness and innovativeness of the country, the lower unemployment and higher employment rates are observed.

2. To conclude, the level of education in Lithuania is higher than the target defined in the strategy "Europe 2020". On the other hand, the focus on R\&D in Lithuania is seen as insufficient ad thus, diminishes competitiveness of the country in the international context.

3. Scientific literature distinguishes various approaches towards the assessment of the investments into high education. The application of IRR method let us reveal that the value of IRR is higher than discount rate $(4 \%>3.5 \%)$. Thus, the investments into high education are beneficial to the State in the long-term period. On the other hand, the research considered one method what has to be assumed as the limitation of the current investigation. 


\section{ENTREPRENEURSHIP AND SUSTAINABILITY ISSUES \\ ISSN 2345-0282 (online) http://jssidoi.org/jesi/ \\ 2016 Volume 3 Number 4 (June)}

4. The obtained data let us suggest putting emphasis on the level of education in Lithuania and the demand of the labour market. Aiming to increase the competitiveness of the country and the employment of qualified individuals, the investments into $R \& D$ have to be increased.

\section{References}

Altonji, J.G.; Blom, E.; Meghir, C. 2012. Heterogeneity in Human Capital Investments: High School Curriculum, College Major, and Careers. Annual Review of Economics 4(1): 185-223.

Ashenfelter, O.; Harmon, C.; Oosterbeek, H. 2003. A review of estimates of the schooling/earnings relationship, with tests for publication bias. National Bureau of Economic Research. Cambridge, p. 1-24.

BIS research. 2013. The benefits of Higher Education participation for individuals and society: key findings and reports "The Quandrants". BIS research paper No. 146.

European Commission. 2010. Fifth Report on Economic, Social and Territorial Cohesion - Investing in Europe's future. Luxembourg: The publications of the EU.

European Commission. 2011. Modernisation of Higher Education in Europe: Funding and the Social Dimension. [Interactive] [Accessed 10 May, 2016.]. Access to Internet: < http://eacea.ec.europa.eu/education/eurydice/thematic_studies_en.php >.

European Commission. 2012. Europe 2020 target: Tertiary education attainment. [Interactive] [Accessed 10 May, 2016 ]. Access through Internet: 〈http://ec.europa.eu/europe2020/pdf/themes/28_tertiary_education.pdf >.

European Commission. 2013. European higher education in te world. [Interactive] [Accessed 10 May, 2016.]. Access through Internet:

<http://www.su.lt/bylos/studijos/Studij_reglam_dok/Lietuv/ek\%20komunikatas\%20del\%20aukstojo\%20mokslo\%20briuselis\% 202013\%2007\%2011\%20com2013_04991t01.pdf>

European Commission. 2014. National Sheets on Education Budgets in Europe 2014. European Commission Education and training. [Interactive] [Accessed 10 May, 2016.]. Access through Internet: <http://eacea.ec.europa.eu/education/eurydice/documents/facts_and_figures/National_Budgets.pdf>

European Commission. 2015. Europe 2020 targets. [Interactive] [Accessed 10 May, 2016.]. Access through Internet: <http://ec.europa.eu/europe2020/europe-2020-in-a-nutshell/targets/index_lt.htm>.

Gižienè, V.; Barkauskas, V. 2010. The importance of intellectual capital on the university management, Engineering economics 15: 498-504.

Gižienè, V.; Markauskienè, A. 2012. The research of the interrelationship between investments into higher education and State incomes and spending, Economics and management 17 (3): 1141-1148.

Gižienè, V.; Vasiliauskaite, A. 2007. Evaluation models of investments to education: application pecularities, Engineering economics 2 (52): 50-58.

Glaeser, E. L.; La Porta, R.; Lopez-de-Silanes, F.; Shleifer, A. 2004. Do institutions cause growth? Journal of Economic Growth 9 (3): 271-303. 


\section{ENTREPRENEURSHIP AND SUSTAINABILITY ISSUES \\ ISSN 2345-0282 (online) http://jssidoi.org/jesi/ \\ 2016 Volume 3 Number 4 (June)}

Gupta, S.; Verhoeven, M.; Tiongson, E.W. 2002. The effectiveness of government spending on education and health care in developing and transition economies, European Journal of Political Economy 18(4): 717-737.

Hazelkorn, E.; Huisman, J. 2008. Higher Education in the 21st Century - Diversity of Missions, Higher Education Policy 21 (2): 147-150.

Korsakienè, R.; Breivytè, I.; Wamboye, E. 2011. Sustainable development and human development index. Journal of security and sustainability issues 1(2): 103-11.

Korsakienè, R.; Diskienè, D, 2015. Do competencies of entrepreneurs and managers influence internationalization processess? Investigation of Lithuanian SMEs. ECIE 2015. Sonning Common, UK : Academic conferences and publishing international limited, ISSN 2049-1050, p. 384-39.

Lankauskienė, T. 2014. Accounting productivity in the sectors of economy: methodological aspects, Entrepreneurship and Sustainability Issues 2(2): 98-106. http://dx.doi.org/10.9770/jesi.2014.2.2(5).

Li, K. W.; Yun, L.; Lui. G. C. S. 2009. Economic performance of human capital in post-reform China, The Chinese Economy 42 (1): 40-61.

Mansur, K.; Kogid, M.; Madais, S. J. 2010. Human capital investment: Literature review analysis and a case study among Kadazan Dusun of Pulutan Village, Medwell Journals 5 (3): 264-269.

Matiušaitytė, R.; Šarkiūnaitè, I. 2003. Human capital significance for economy and management, Bridges: humanitarian and social sciences 13 (1): 293-304.

McMahon, W. 2007. An analysis of education externalities with applications to development in the Deep South. Contemporary Economic Policy 23 (3): 459-82.

Ministry of Education and Science. 2013. Lietuvos švietimas Europos švietimo siekių kontekste. ISSN 1822-4156. Nr. 9 (95). [Interactive] [Accessed 11 April 2016]. Access through Internet: < http://www.smm.lt/uploads/documents/tyrimai_ir_analizes/Leidiniai\%202013/Lietuvos\%20\%C5\%A1vietimas\%20Europos\%2 0\%C5\%A1 vietimo\%20sieki\%C5\%B3\%20kontekste\%20\%282013\%2011\%29.pdf >.

Narayan, P.K.; Smyth, R. 2007. Higher education, real income and real investment in China: evidence from granger causality tests, Education Economics 14 (1): 107-125.

Nureyev, R. M. 2010. Human capital and its development in present-day Russia, Russian Education \& Society 52 (3): 3-29.

OECD. 2007. Innovation and growth. OECD indicators, OECD publishing.

OECD. 2014. Education at a glance 2014. OECD indicators, OECD publishing.

Pargaru, I.; Gherghina, R.; Duca, I. 2009. The role of education in the knowledge-based society during the economic crisis, Annales Universitatis Apulensis Series Oeconomica 11 (2): 646-651.

Potelienè, S.; Tamašauskienė, Z. 2014. Human capital conceptualization: development and concept formation, Business systems and economics 4 (1): 89-106.

Psacharopoulos, G. 1995. The profitability of investments in education: concepts and methods. HCO.

Saint, W. 2015. Tertiary Education and Economic Growth in Sub-Saharan Africa: The World Bank Report. International Higher Education 54: 14-15. 


\section{ENTREPRENEURSHIP AND SUSTAINABILITY ISSUES \\ ISSN 2345-0282 (online) http://jssidoi.org/jesi/ \\ 2016 Volume 3 Number 4 (June)}

Seniūnaitè, L. 2002. Country development influence of human capital. The problems of human capital formation. Economics and management, 43-45.

Statistics Lithuania. 2014. The funds per one individual. [Interactive] [Accessed 15 May 2016] <http://osp.stat.gov.lt/web/guest/statistiniu-rodikliu-analize?portletFormName=visualization \&hash=3b61ef5f-bb22-477b-8136ea59535e9bcf>.

Stroombergen, A.; Rose, D.; Nana, G. 2003. Review of the Statistical Measurement of Human Capital. Statistics New Zealand: Infometrics consulting, business and economic research Ltd.

Tarábková, L. 2014. Model of motivating linked-up with education, Entrepreneurship and Sustainability Issues 2(1): 12-18. DOI; http://dx.doi.org/10.9770/jesi.2014.2.1(2).

Tunčikienè, Ž.; Korsakienè, R. 2014 Sustainable development of public institutions: the model of functional review, Journal of security and sustainability issues 4(2): 187-195.

Woessmann, L.; Schuetz. G. 2006. Efficiency and Equity in European Education and Training Systems. European expert network on economics of education. Analytical Report No. 1 Prepared for the European Commission.

Justina PRAKAPAVIČIŪTÉ - Master's degree student at Business Management Faculty, Vilnius Gediminas Technical University. Her research interests involve: human capital and investments.

Renata KORSAKIENE - PhD, works as Associate Professor at the Department of Economics and Management of Enterprises, Vilnius Gediminas Technical University. She authored and co-authored more than 80 scientific papers, published in scientific journals and conference proceedings. Her research interests involve: strategic management, internationalisation and international entrepreneurship, entrepreneurship and human capital.

Copyright (C) 2016 by author(s) and VsI Entrepreneurship and Sustainability Center This work is licensed under the Creative Commons Attribution International License (CC BY). http://creativecommons.org/licenses/by/4.0/

(c) (i) Open Access

